Software \& Systems

Received 03.10 .18

DOI: $10.15827 / 0236-235 X .124 .697-704$

2018, vol. 31, no. 4,pp. 697-704

\title{
Building a specialist's knowledge model in the digital economy
}

\author{
G.P. Vinogradov 1, Dr.Sc. (Engineering), Professor, wgp272ng@mail.ru \\ N.G. Vinogradova ${ }^{1}$, Postgraduate Student \\ D.A. Shapel 2, Head of Sector IT, dez788@yandex.ru
}

1 Tver State Technical University, Tver, 170026, Russian Federation

${ }^{2} R \& D$ Institute Centerprogramsystem, Tver, 170024, Russian Federation

\begin{abstract}
The purpose of the study is to investigate the problem of forming a training standard and the construction of a higher education specialist knowledge model. These problems are considered important when managing the process of professional personnel training for the digital economy.

The authors used the methods of system analysis, the theory of active systems, the theory of information management, coordinated management in organizational systems, methods and approaches of the artificial intelligence theory.

The research shows that Russia's entry into the Bologna Process caused some downturns. Specialists' training effectiveness and quality has become lower. It has become difficult to integrate higher education institutions into a new social and economic system of the country. Specialists' training goals, including the goals at all training stages, do not conform to the goals of economic entities. At the same time, universities are the ones who are mainly responsible for training specialists who meet the requirements of the digital economy. One of the ways to overcome these downturns might be the transition of universities to the design and technological type of work organization. Then the most promising form of educational project management is the implementation of the model of information interaction between parties concerned (organizations and universities) within the framework of active self-developing network expert environments.

The paper presents the structure of an active self-developing network expert environment and its functioning principles when forming specialist's model standards and knowledge. This approach allows considering the construction of training standards and development of a specialist knowledge model in the context of corporate intellectual potential management strategies. The implementation of this approach is a multi-stage process of collecting, analyzing, evaluating and processing large amounts of information. The authors propose a system that provides searching, filtering, summarizing information, determining its value and prospects. It is established that the method of improving the quality of educational project decisions is the synthesis of network expertise technologies and the methodology of the theory of active systems.

The paper shows that the effective formation of training standards and a specialists' knowledge model is possible within the framework of self-organizing expert environments that are presented as active systems with heterogeneous agents with a counter method of communicating information with the active influence of the center. The effective implementation of this approach implies changing the goals of the higher education system from meeting the needs for training higher education personnel шт order to develop an innovative economy. This will ensure the interaction of universities and organizations in the management of their intellectual capital in the digital economy on a new legislative basis.
\end{abstract}

Keywords: digital economy, knowledge model, active system, education system, coordinated management, self-organizing expert environments.

Nowadays, the national economy security depends on the development of high-tech goods and services industries. Modern network forms of business organization, in which innovative activities will be directed through digital platforms, will play the leading role in this process. They will help to solve the innovation management problem. Its purpose is to integrate intellectual and productive resources of organizations based on cognitive technologies in order to identify, accumulate and use knowledge while aiming to automate business processes.

In this situation, Russia's entry into the Bologna Process evoked the problem of specialists' training effectiveness and quality, as well as the problem of integrating higher education institutions into a new social and economic system of the country. According to the principle of institutional autonomy, the primary responsibility for their solution rests with universities [1]. The method of solution is the transition of higher education institutions to the design and technological business type. The relevance of works related to educational projects is also due to the dynamics of scientific and technical progress and the transition to the economy of information interactions [2-4].

A big number of papers has been dedicated to the problem of designing a specialist's knowledge model. The bibliography is given in [5-9]. Nevertheless, the problem remains important. The system of personnel training is lagging behind the public demand, industry, etc. [1]. This is due to the fact that the source of changes in the social and economic system of the country and regions is outside the universities due to the specifics of the university system.

Under fast pace of changing development paradigms, it is rather difficult to monitor the observed and future sources, which cause the evolution of socio-economic systems. The corresponding subject area is poorly structured. It is characterized by great uncertainty and most importantly knowledge distribution between carriers [10]. Therefore, the task of knowledge model design should be solved as a task of collective decision-making on a set of agreed compromise versions of curricula for training specialists [11]. 


\section{The principles of creation and application of educational project management systems}

A university is an educational organization that is created to meet the individual's need for higher education and the needs of society and government in qualified specialists through the provision of educational services. The most promising form of educational project management is the model of information interaction within the framework of active self-developing network expert communities [2]. Such environment contains many experts who are professionals in a relevant field. Appropriate information technologies and Internet facilities provide their communicative interaction. This, in turn, creates the education basis due to a synergetic effect during network interaction of expert professionals of a collective strategic entity that is a carrier of coordinated views and knowledge of the model of specialist's knowledge and competencies. The structure of an active self-developing network expert environment should take into account at least two principles.

The principle of an active external environment. The main elements of the university external environment are educational institutions of secondary education, consumers of educational services and competitive universities in the market of educational services. Therefore, to ensure a balance between internal and external activities of the university, it should be considered as an active multi-agent system (Fig. 1).

According to such approach to structuring a university environment, the scheme in Fig. 1 puts into correspondence a two-level active multi-agent system. One of the ways to increase the effectiveness of this system is to analyze the needs of consumers in educational services. Naturally, a consumer should have knowledge of the capabilities of universities. This creates the prerequisites for determination of agreed desired states in the space of indicators, both for consumers of educational services and for a university. It also allows choosing the direction and ways of achieving them through determination of an agreed list of competencies, knowledge, skills, structure and the content of trans- ferred knowledge. This way of translating knowledge allows adapting to the requirements of the educational services market, additionally diversifying it.

2. The coalition principle. This principle involves creation of an active self-organizing expert environment and a structure of an interdisciplinary research system according to the subject-oriented approach. The structure includes a center for interdisciplinary and transdisciplinary studies in the management of educational projects. It includes representatives of various scientific fields and a head of interdisciplinary and transdisciplinary studies in the management of educational projects. The composition of the research group and building models for managing educational projects is formed using the mathematics of the theory of active systems and the information technology of agreement. The Center claimed to be a coalition for the development of a research methodology on the formation of an educational project content.

\section{A mechanism of self-organization of network expert systems in the problem of managing the evolution of specialist knowledge model}

Building a specialist knowledge model should be considered in the context of corporate knowledge management strategies to enhance competitiveness of a company. The created support systems of a company knowledge life cycle and the integral knowledge model of a specialist are used to integrate strategic corporate tasks with strategic tasks of developing corporate knowledge of employees. A specialist is considered as an element of a company production system. His purpose is to assign a product with specified quantitative and qualitative parameters to ensure its competitive advantages. In order to carry out production activities, a specialist uses a complex of abilities, knowledge and skills that should be considered as models of his production and technological activities. At each moment, this complex should be considered as a subjective model of its production and technological activity [12].

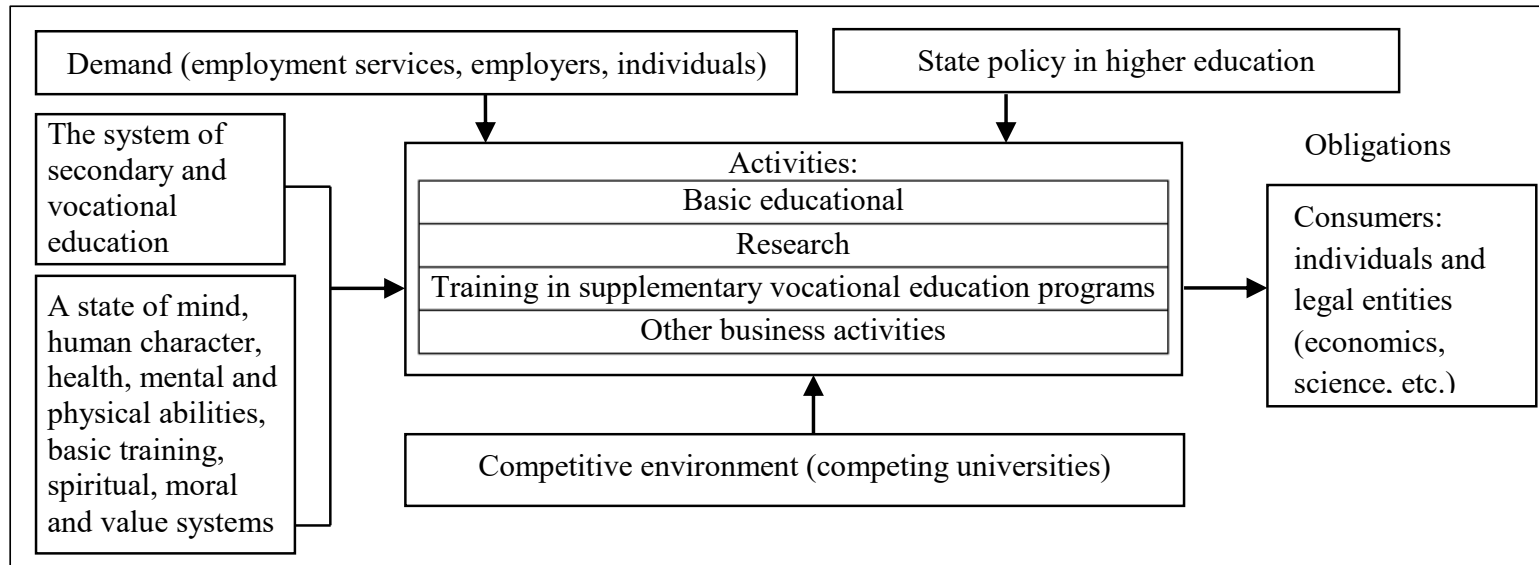

Fig. 1. The activity structure of a university 
Specialist knowledge management is a way to profit by improving the effectiveness and quality of his behavior in solving production problems. The behavior of a specialist in a company is determined by: 1) his expectations in meeting his needs as an individual; 2) his qualities as a person and a specialist, some of which are formed under the influence of activity; 3 ) evaluation of the results of his activities by the company and his subjective assessment. An activity has obvious and implicit behavioral indicators, their data are in the activity results. Applied methods of action and their observed effectiveness, the obtained results contain information about a pattern of behavior. Modeling of behavioral patterns from three positions was considered in [13]. The discrepancy between the actual and required knowledge model determines requirements for investing in a knowledge system of an organization and hence to target indicators of a university educational process. Network technologies create a mechanism for identifying requirements for the quality and structure of educational services, determining the direction of their development. They are the basis for information support for the innovative process of transforming a knowledge and competencies model of a specialist, which forms the basis for a self-development process of a university. An important component of the process is the system that directs the search for solutions and ideas for making decisions on building a specialist model. The basis for its creation should be the synthesis of crowdsourcing, network expertise and methodology of the theory of active systems (Fig. 2).

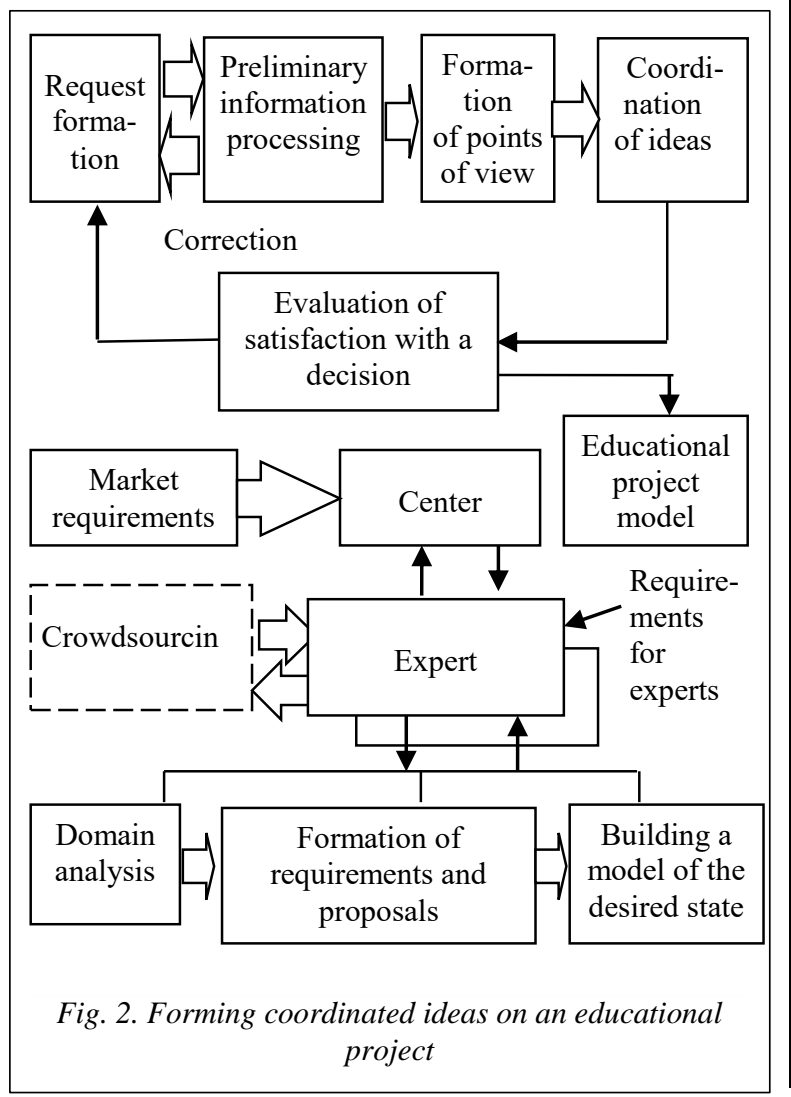

The proposed approach allows considering the process of extracting new ideas and knowledge as an active system with heterogeneous agents with a counter way of communicating information and active influence of a center in the form of queries to obtain reflexive estimates $[14,15]$.

The information exchange between the center and experts is an interactive and iterative process. In this case, crowdsourcing tools are used for preliminary processing of information coming from experts, including filtering, characterization, semantic clustering, building ontologies, etc. Processing is aimed at speeding up the process of building an agreed choice model in a network expertise and its translation into the system environment using data mining tools. The center completes semantic clustering and a subject domain ontology, forms a model of a specialist, assesses the consistency of various solutions, develops its own version on their basis, and performs its evaluation. To coordinate it, the center forms queries and informs experts of its solution. The information exchange between the center and experts continues until a solution is agreed. Methods for describing a structure of representations of active environment subjects, conditions for identity, regularity, correctness, differences in information awareness of subjects, as well as conditions for dynamic information equilibrium existence, and models of coordinating representations in the communication process are given in $[10,15]$.

\section{Reflexive coordinated management of an educational project}

Achieving the goal of the project involves formation of a coordinated decision on the model of competences and knowledge, fixing it as beliefs among students, methods, means of developing creative thinking and ways of acting in typical situations. To solve this task means to activate all kinds of reflective thinking among project participants. Before choosing a solution, it is necessary to obtain information about possible alternatives (for example, as a range of solution options). Necessary conditions for their formation are information actions performed according to the TOTE model developed by R. Bandler and R. Dilts [16]. This model makes it possible to describe and form human mental and behavioral programs to achieve the goal through a variety of means. Description models using the concept of TOTE are well formalized by structural programming and can be successfully described using algorithms.

The behavior of agents who are project participants is determined by their model of subjective representations, which connects a state of agent's environment, modes of its operation and a result (material or spiritual). When planning their behavior, agents predict a state of the environment, possible results, their value, a mode of action. When assessing a result of their behavior, agents monitor and evaluate their performed actions, obtained results, a value of a result and value 
of their behavior in general. These assessments form states of satisfaction and conviction. Satisfaction represents an integral feeling or emotion. It is determined by a combination of specific, particular feelings and emotions from the obtained result or the possibility of obtaining it. In the process of behavior, an agent solves some problems. The task is the desired result the agent seeks for some time, and he breaks the task into a sequence of steps to achieve it. At each stage $k$, the agent edges towards a solution of a problem, and the expected value of an intermediate result (the objective function $\left.f\left(y_{j}[k]\right)\right)$ increases monotonically following its results. The corresponding algorithm consists of the following steps $[10,17]$.

1. Statement of a decision making problem, $k=0$.

2. $k=k+1$.

3. Search for the mode of action $y_{j}[k]$.

4. Evaluation of the objective function $f\left(y_{j}[k]\right)$.

5. Satisfaction survey.

6. If " $o$ key", then the task is solved and the search process stops. Otherwise the search for a solution continues and there goes the transition to step 2.

Here $f(o k e y)[k]$ is the satisfaction function; $s[k]$ is the search cost function (psychological, temporal, material, etc. $)$, increases monotonically by $k ; f(o k e y)[k]=$ $=\max \left\{f\left(y_{j}[k]\right)-s[k] \mid k \in K\right\}$ is the satisfaction condition.

Let us introduce a formal description of the hypothesis of the expert's rational behavior $y(o$ key $)=$ $=\operatorname{Argmax}\left\{f\left(y_{j}[k]\right)-s[k] \mid k \in K\right\}$.

The expert can solve the problem of modeling individually or as part of a decision-making group, which includes a purposeful center and other purposeful agents. In the first case, he chooses a solution to the problem that satisfies him or manifests a desire to get the optimal result. However, he must be convinced of the possibility of obtaining it. In the second case, purposeful agents choose a solution to the problem that satisfies all single-minded agents, and all of them are convinced of this (evaluation of decisions). The optimal solution to the problem is sought in the course of coordinated optimization of satisfactory solutions to the problem. Measuring the values of the membership functions of elements of fuzzy sets (for example, ideals or goals), which are measures of the intensity of satisfaction and conviction of a single-minded agent (expert) is carried out with the help of linguistic and representative variables, criteria and goals. To evaluate the degree of consistency of solutions, a linear convolution algorithm with significance coefficients is used.

When decisions of the participants are agreed, as in expert assessment methods, a set of criteria for specific $j$-th participants is compared with the experience in the "experiment". Let us consider a certain goal and its corresponding criterion $k(w)$. We will perform its decomposition, obtain a second level objective tree and a corresponding tree of criteria:

$$
\begin{aligned}
& \mu_{D}(k(w))= \\
& =\sum_{i=1}^{n} a_{i}(k(w)) \times \mu_{G_{i}}(k(w))+\sum_{j=1}^{m} \beta_{j}(k(w)) \times \mu_{C_{j}}(k(w)),
\end{aligned}
$$

where $a_{i}, \beta_{j}$ are coefficients of criteria significance for which the following equation is true:

$$
\begin{aligned}
& \sum_{i=1}^{n} a_{i}(k(w)) \times \mu_{G_{i}}(k(w))+ \\
& +\sum_{j=1}^{m} \beta_{j}(k(w)) \times \mu_{C_{j}}(k(w))=1 .
\end{aligned}
$$

Here, there are membership functions of subjective ideals and goals of purposeful agents. A membership function of an ideal and a goal is determined using associations, intersections and their combinations of fuzzy sets of ideals, goals and constraints of the second, third and further levels.

Let us consider goals in the form of associations of fuzzy sets at each level [13]. There can be several levels. For the sake of simplicity, we will consider two levels. Let there be $m$ goals at the second level. We define $\mu_{D}(w)=\bigcap_{j}^{m} \mu_{G_{j}}(w)$, or taking into account the significance coefficients $\mu_{D}(w)=\bigcap_{j}^{m} a_{j} \mu_{G j}(w)$, therefore

$$
\mu_{D}(w)=\mu\left(\bigcap_{j}^{m} a_{j} \mu_{G j}(w)\right)=\min \left\{a_{j} \mu_{G j}(w)\right\} .
$$

The next level has several goals $G_{i j}, i=1, \ldots, n$, $j=1, \ldots, m$,

$$
\begin{aligned}
& \left(\mu_{D}(w)=\bigcup_{i}^{n} a_{i}\left(\bigcap_{j}^{m} a_{i j} \mu_{G i j}(w)\right),\right. \\
& \mu_{D}(w)=\bigcap_{i}^{n} a_{i}\left(a_{i j} \bigcup_{j}^{m} \mu_{G i j}(w)\right), \\
& \mu(A \vee B)=\oplus\left(\mu_{a}, \mu_{b}\right)=\max \left\{\mu_{a}, \mu_{b}\right\}, \\
& \mu(A \wedge B)=\otimes\left(\mu_{a}, \mu_{b}\right)=\min \left\{\mu_{a}, \mu_{b}\right\} .
\end{aligned}
$$

Convolution of particular indicators into a complex estimation is performed using network programming methods, which are based on the representation of an objective function and problem constraints as a superposition of simpler functions [18]. If an expert is satisfied with the received solution and image in the form of TOTE, sure of this and agrees with this, then he proceeds to forming the next TOTE, i.e. to the next part of an educational project according to the hierarchical structure of the set of forming TOTE. Otherwise, the whole procedure is repeated. At the same time, the information coordination technology should coordinate information of a conscious and unconscious expert.

To describe a group behavior of experts in informal and formal communication we apply a model of the constant updating of IWRA knowledge [16]. I means individual contributions of each expert to the solution of a common task $(\mathbf{W})$ based on insight, intuition and knowledge with different values and abilities. Based on communicative interaction, experts develop an agreed view of a choice situation, determine the direction of advance towards the subjectively understood ideal, and develop adjustments $(\mathbf{A})$ in organizing and developing ways of acting to achieve a common goal. 


\section{Making agreed decisions in the problem of forming a knowledge and competencies model of a specialist}

For the purposes of a formal analysis of self-organizing expert system functioning (Fig. 1), we will consider its model, which consists of an interdisciplinary research center and experts (agents). According to $[15,19]$ the functional problems of the center are:

- formation of an agreed perception of the state of corporate knowledge management strategies in companies and the possibility of a university to participate in their implementation;

- formation of an agreed idea on the educational services structure and content in a purposeful state situation;

- determination and coordination of university survival and development goals based on agreed ideas;

- development of coordinated management taking into account the interests of a university and consumers of educational services;

- optimization of generalized indicators of system performance effectiveness.

Let $u$ be the center control (a version of a curriculum and a competency list), a $v=\left(v_{1}, v_{2}, \ldots, v_{n}\right)$ is a vector of agent controls (informational reports of experts). The last two problems can be solved as follows:

$(u, v) \in \Omega$,

where $\Omega$ is a set of controls that convert the system into one of the states of the set $X^{*}\left(X^{*} \subset X\right.$ is an area of desired states of the system).

Controls (1) might be determined based on some set of assumptions about a behavior and nature of system agents' awareness.

1. The center can define the desired state of the system as a set of generalized indicators that are functions of parameters of agent messages. Generally, the center does not know particular dependencies. However, to determine them, it can use information about the results obtained by competitors in this market sector and the results of network expertise. We will call such inferred knowledge the perception of the center about the state of a company knowledge system, possibilities and direction of educational system development.

2. Based on agents' messages and representations of desired states, the center can determine management (a plan of actions and information request) $u \in U$ and inform its agents.

3. And inform its agents $u$, the $i$-th agent choses its control $v_{i} \in V_{i}\left(u_{i}\right)$, which converts him into the state $y_{i} \in Y_{i}$, where $Y_{i}$ is a set of possible states. We will assume that agents are interdependent in the choice of their states. It means that they consider global constraints $Y^{\text {гл. }}$ when choosing. Therefore, according to the condition (1), the system can be in one of the following states $Y=Y^{\text {гл. }} \cap \prod_{i=1}^{n} Y_{i}$. Here $\prod_{i=1}^{n} Y_{i}$ is a set that is determined by local restrictions that experts know.
4. Let agent's behavior correspond to the hypothesis of rational behavior. Then the choice of the agent's message will be aimed to maximize its subjectively understood effectiveness criterion $G_{i}\left(u, v_{i}\right)$.

5. In general, the center does not know exactly about control space and agents' effectiveness criteria. So it must organize information exchange with agents to create his vision of their desired states. For this purpose, he requests the agents to assess the quality of their views $u$ and desired states $y_{i}$, clarifies their interests around the obtained solution in exchange for incentives for receiving counter information.

6. After receiving new information, the center recounts the solution and asks agents new questions until he receives an exact or close solution.

These assumptions allow formulating a problem of determining a set of specialist model variants by the center as a set of his admissible controls

$$
\begin{aligned}
& U^{0}=\left\{u \in U \mid V(u)=\prod_{i=1}^{n} V_{i}(u) \neq \varnothing,\right. \\
& \left.(u, v) \in \Omega, \quad \forall v \in R(u)=\prod_{i=1}^{n} R_{i}(u)\right\},
\end{aligned}
$$

where $R_{i}(u)=\operatorname{Arg} \max _{v_{i} \in V_{i}(u)} G_{i}\left(u, v_{i}\right)$.

Let the center estimate the states of satisfaction and conviction from the obtained version of a specialist knowledge and competences model using an efficiency criterion $F(u, v)$, then he can form such version of messages for experts that is optimal guaranteeing control for him $u^{0} \in U^{0}$, determined as:

$$
F^{0}=\sup _{u \in U^{0}} \inf _{v \in R(u)} F(u, v)
$$

Common interests of the center and agents are guaranteed by the condition of obtaining total benefit

$$
\sum_{i=1}^{n} G\left(u_{i}, v_{i}\right)+F^{0} \leq C(\bar{Y}),
$$

where $\bar{Y}$ is the expected profit from a company knowledge system development, $C(\bullet)$ is a material incentive fund or a pay-roll fund for experts.

Consequently, the considered system is a system with interests that are no opposite, since the amount of income received depends on their total efforts. Then the choice of an agreed vision of a knowledge model and specialist's competencies should be made using a variety of compromise options. The purpose of an agreement is to achieve terminal payoff. It can be succeed by reporting reliable information and cooperative solving problems, which is a guarantee of convergence of data exchange.

The structure and content of expert's messages is determined by solving the following problem. Each $i$-th agent builds a model of a management object describing it with a level of costs $y_{i}^{\text {Bx. }}$, a level of output $y_{i}^{\text {Bыx. }}$ and a set of action modes $z_{i}$, by which an agent guarantees the output of products and services of the required assortment and quality. The modes of action 
$z_{i}$ are determined by its competencies, knowledge and experience. Then the considered set of possible states of $i$-th agent is determined as follows:

$$
\begin{aligned}
& Y_{i}=\left\{y_{i} \mid \bar{y}_{i}^{\mathrm{BX} .} \leq y_{i}^{\mathrm{BX} .} \leq \bar{y}_{i}^{\mathrm{BX} .},\right. \\
& \left.y_{i}^{\mathrm{Bbx} .}=w_{i}\left(y_{i}^{\mathrm{BX} .}, z_{i}\right) \in Y_{i}^{\mathrm{Bbx} .}, z_{i} \in Z_{i}\right\} .
\end{aligned}
$$

The task (1-5) of determining a knowledge model and competence should be considered as the task of searching a maximin with bound constraints.

When determining the mode of action, the $i$-th agent solves its locally optimal problem. So, $y_{i}^{\text {Bdx. }}=w_{i}^{*}\left(y_{i}^{\text {Bx. }}, z_{i}\right) \in Y_{i}^{\text {выx. }}$ should be considered as a model of agent's vision of control object operation. Therefore,

$Y_{i}^{*}=\left\{y_{i} \mid \bar{y}_{i}^{\mathrm{BX} .} \leq y_{i}^{\mathrm{BX} .} \leq \bar{y}_{i}^{\mathrm{BX} .}, y_{i}^{\mathrm{Bdx} .}=w_{i}^{*}\left(y_{i}^{\mathrm{BX} .}, z_{i}\right) \in Y_{i}^{\mathrm{Bdx} .}\right.$, $\left.z_{i} \in Z_{i}\right\}$ can be considered as agent's subjective vision of the set of possible states that he can communicate to the center. Obviously, it is determined by his knowledge, experience and corporate strategies of his development.

The center forms its own vision of knowledge system development in corporations and companies taking into account national interests

$$
Y_{i}^{*}=\left\{y_{i} \mid \bar{y}_{i}^{\mathrm{BX} .} \leq y_{i}^{\mathrm{BX} .} \leq \bar{y}_{i}^{\mathrm{BX} .}, y_{i}^{\mathrm{Bdx} .}=w_{i}^{\amalg}\left(y_{i}^{\mathrm{Bx}}, z_{i}\right) \in Y_{i}^{\mathrm{Bdx} .},\right.
$$$$
\left.z_{i} \in Z_{i}\right\}
$$

The desire of organizations to increase their effectiveness and competitiveness makes it possible to guarantee that the center will be fully informed of capabilities, desired states of agent's knowledge system within the accuracy of parameters. It means that the center receives all necessary information about models of competencies and knowledge of specialists from agents, but does not know their choice. In [20] it is shown that based on this knowledge the center calculates control $u^{0} \in U^{0}$, and an agent makes only one information message by selecting its state $y_{i}$ and control $v_{i}$ from the set $B_{i}\left(u_{i}\right)=Y_{i}\left(u_{i}\right) \cap Y_{i} v_{i}$, maximizing the value of its objective function

$$
G_{i}\left(u_{i}, v_{i}\right) \underset{v_{i} \in B_{i}\left(u_{i}\right)}{\rightarrow} \max .
$$

Therefore, the center has the result of choice of all agents belonging to the set $R(D)$, where $D=Y^{\text {гл. }} \cap \coprod_{i=1}^{n} B_{i}\left(u_{i}\right)$ is a set of possible states of the whole system. Changing the control $u=\left\{u_{i}, i=\overline{1, n}\right\}$, the center can play possible scenarios of system behavior.

\section{The algorithm for constructing a set of possible messages by an agent}

An agent determines the direction of his development by analyzing his opportunities and trends in market dynamics. When the center communicates a version of a competence and knowledge model $u_{k}$ the agent can determine for himself, by solving the problem (6), such a vector of vision of a knowledge model $x_{k}^{(h)}$, that allows expanding the set $X_{k}^{(h)}$ of center's visions of his needs, where $h$ is a step of the iteration process [19]. We denote a vector of expansion parameters of the set of possible states of an organization knowledge model through $\omega_{k}=\left\{\omega_{k}^{(h)}, h=1, H\right\} \in A_{k}$. Obviously, it will determine the values of the vector $x_{k}^{(h)}=\left\{x_{k j}^{(h)}, j \in\left[\overline{1, m_{k}}\right]\right\} \in X_{k}^{(h)}$. Therefore, this vector describes agent's knowledge of the possibilities of developing an organization knowledge system. Here $A_{k}$ is a set of possible values of the state vector. We assume that an agent has abilities that guarantee existence $\Psi_{k}: A_{k} \rightarrow X_{k}^{(h)}$. So he is able to change his knowledge system for the company.

A level of knowledge about requirements of the market to the volume and quality of produced products and services available to an agent makes it possible to assume the existence of a limited set of $A_{k}$ state parameters for the $k$-th agent. Let us denote an achievability set or a set of limit possibilities through $O_{k}^{*}=$ $=\left\{o_{k}^{*} \mid o_{k}\left(x_{k}\right), x_{k} \in X_{k}^{(h)}\left(\omega_{k}^{(h)}\right), \omega_{k}^{(h)} \in A_{k}\right\}$. According to the hypothesis for locally optimal agent behavior, due to his creative abilities, self-learning and searching for new information under appropriate stimulating influence, an agent is able to determine such states $\omega_{k}^{(1)} \in A_{k}$ and $\omega_{k}^{(2)} \in A_{k}$, that $\omega_{k}^{(2)} \succ \omega_{k}^{(1)}$ is possible, where the symbol $\succ$ means "more meaningful". At the same time $X_{k}^{(1)}\left(\omega_{k}^{(1)}\right) \subseteq X_{k}^{(2)}\left(\omega_{k}^{(2)}\right)$. Therefore, there exists a sequence $\omega_{k}^{(1)}, \omega_{k}^{(2)}, \omega_{k}^{(3)}, \ldots$, so that $\lim _{h \rightarrow \infty} o_{k}^{(h)}\left(x_{k}^{(h)}\left(\omega_{k}^{(h)}\right)\right)=O_{k}^{*}$. It guarantees that an agent gives the center reliable information about requirements for a specialist competency and knowledge model. Agent's ability to form an expanding set of knowledge and competencies model options results from the following properties of his target function:

$$
\begin{aligned}
\forall \omega_{k}^{(1)}, \omega_{k}^{(2)} \in A_{k}, \omega_{k}^{(2)} & \succ \omega_{k}^{(1)}, \\
X_{k}^{(1)}\left(\omega_{k}^{(1)}\right) \subseteq X_{k}^{(2)}\left(\omega_{k}^{(2)}\right) & \mapsto E \varphi_{k}\left(x_{k}^{(2)}\right)>E \varphi_{k}\left(x_{k}^{(1)}\right) .
\end{aligned}
$$

This condition determines agent's motivation and purposefulness. So, when crossing a certain threshold of changing the value of a purposeful state situation by the result of $\Delta=E \varphi_{k}\left(x_{k}^{(2)}\right)-E \varphi_{k}\left(x_{k}^{(1)}\right)$, an agent is able to identify preferred modes of action and sees the possibilities of changing the structure of his knowledge.

\section{Proposals for program implementation by digital platform means}

It is most reasonable to implement the proposed scheme of forming a specialist's knowledge model using an applied digital platform. 
The digital platform is a communication and transactional environment, the participants of which (as shown above) benefit from interaction with each other. In this case, it represents a business model that provides a structured algorithmic interaction of platform participants in a certain way. The purpose of interaction is the exchange of information about the profile of the knowledge used in business processes in organizations and industries, requirements for quantity and quality of specialist's competencies by conducting transactions in a single information environment. The result of such interaction is an agreed qualification list of higher education specialists, the corresponding state standards and training curriculum. The means of achieving the goal is the use of digital technologies for forming a network structure of interacting economic agents and universities, intelligent tools for collecting and processing information, a unified technology for the interaction of participants.

In fact, information and communication technologies have given a technical opportunity to ensure the "visibility" of university resources in providing the required volume and quality of educational and research services for their consumers, as well as to ensure mutual settlements between universities and economic agents.

The effectiveness of the platform business model in the higher education system and the development of intraplatform competition are determined by the following important factors: is the growth of a platform client base self-developing; are there positive feedback between the growth of a specialists' consumer base and a university base.

Technical solutions on building a platform business model in the higher education system can be adopted from the solutions on creating the Google Internet advertising platform (many advertisers have access to many users of the Google search service), the Uber taxi service platform (many transporters have access to many passengers), the application store for Apple's iOS operation system (application providers have access to Apple mobile device users), the Airbnb rental platform (owners have access to a renters), the Booking.com platform for booking hotel rooms (accommodation businesses have access to travellers), and others.

\section{Conclusion}

The paper describes an attempt to research educational project management using a transdisciplinary approach. The research applies modern approaches of the theory of active systems, psychology, neurolinguistic programming, management in social and economic systems. The authors consider the problem of investigating reflexive management processes in formation of a knowledge and competences model, which is an important part of educational projects, especially for new promising areas that have no analogues. Its solution is associated with management tasks, personal knowledge of experts, and corporate strategies for managing an organization knowledge system. Experts are considered as carriers of new knowledge obtained in active scientific research. It is shown that the formation of a specialist knowledge and competence model in the context of uncertain and poorly structured information is in implementation of consistent procedures for agreeing the views of producers and consumers of educational services.

Acknowledgements. The work has been financially supported by RFBR, project no. 170100728 .

\section{References}

1. Novikov A.M., Novikov D.A. Educational Project (Methodology of Educational Activities). Moscow, Egves Publ., 2004, $120 \mathrm{p}$.

2. Vinogradov G.P., Vinogradova N.G. Self-organizing network expert environments in systems with endogenous targeting principle. Ontology of Designing. 2016, vol. 6, no. 1, pp. 36-54 (in Russ.). DOI: 10.18287/2223-9537-2016-6-1-39-54.

3. Mamaev V.Ya. Models and algorithms for monitoring and estimation of knowledge in an intelligent learning system. Scientific Instrumentation. 2001, vol. 11, no. 4, pp. 84-87 (in Russ.).

4. Loban A.V., Lovtsov D.A. A computer-training model using a new-generation electronic educational resource. Open Education. 2017, no. 2, pp. 47-55 (in Russ.). DOI: 10.21686/1818-42432017-2-47-55.

5. Naykhanova L.V., Dambaeva S.V. Methods and Algorithms of Decision-Making in the educational Process Management Under Uncertainty. Monograph. Ulan-Ude, VSGTU Publ., 2004, 164 p.

6. Dorrer G.A., Rudakova G.M., Gorbachenko I.M. Probabilistic model of an interactive learning process. Open Education. 2001, no. 2 .

7. Lednev V.S. The Content of Education. The Essence, Structure, Prospects. Moscow, Vysshaya shkola Publ., 1991, 224 p.

8. Krasilnikova V.A. The Use of Information and Communication Technologies in Education. Orenburg, OGU Publ., 2012, $291 \mathrm{p}$.

9. Information and Telecommunication Technologies in Education. Monograph. B. Dendev (Ed.). Moscow, IITO YuNESKO Publ., 2013, 320 p.

10. Kuznetsov V.N. Harmonization Methodology in Economic Information Systems. PhD Thesis. Moscow, 1998, 309 p.

11. Mikhalevich V.S., Volkovich V.L. Computational methods in complex system design. Moscow, Nauka Publ., 1982, 286 p.

12. Vinogradov G.P. A Subjectve Rational Choice. IOP Conf. Series: J. of Physics. 2017, vol. 803, article 012176. DOI: 10.1088/1742-6506/803/1/012176.

13. Bellman R.E., Zadeh L.A. Decision-making in fuzzy environment. Management Science. 1970, vol. 17, no. 4, pp. 141-160 (Russ. ed.: Moscow, Mir Publ., 1976, pp. 172-215).

14. Network Expertise. 2-nd ed. D.A. Novikov, A.N. Raykov (Eds.). Moscow, Egves Publ., 2011, 166 p.

15. Vinogradov G.P., Ivashkin Yu.A. Modeling negotiation processes in high-tech production systems. Systems of Control, Communication and Security. 2016, no. 2, pp. 202-248. Available at: http://sccs.intelgr.com/archive/2016-02/08-Vinogradov.pdf (accessed October 03, 2018)

16. Bendler R. Guidelines for Changing Personality. Moscow, Eksmo Publ., 2010, 208 p.

17. Velichkovsky B.M. Cognitive science: Fundamentals of the Cognitive Psychology. Moscow, Smysl: Akademiya Publ., 2006, vol. 2, $432 \mathrm{p}$.

18. Moiseev N.N. Mathematical Problems of System Analysis. Moscow, Nauka, Fizmatlit Publ., 1981, 488 p.

19. Burkov V.N., Novikov D.A. How to Manage Organizations. Moscow, Sinteg Publ., 2004, 400 p.

20. Kalyanov G.N. It-consultant training in the context of domestic consulting issues. Open Education. 2017, no. 2, pp. 40-46 (in Russ.). DOI: 10.21686/1818-4243-2017-2-40-46. 
Построение модели знаний специалиста в цифровой экономике

Г.П. Виноградов ${ }^{1}$, д.m.н., nрофессор,wgp272ng@mail.ru

Н.Г. Виноградова ${ }^{1}$, аспиранm,wgp272ng@mail.ru

Д.А. Шапель ${ }^{2}$, зав. сектором информациинных технологий, dez788@yandex.ru

${ }^{1}$ Тверской государственный технический университет, г. Тверь, 170026, Россия

${ }^{2}$ НИИ «Центрпрограммсистем», г. Тверь, 170024, Россия

Целью работы является исследование проблем формирования стандарта подготовки и построения модели знаний специалиста с высшим образованием. Эти проблемы в числе центральных при управлении процессами подготовки профессиональных кадров для цифровой экономики.

В работе использовались методы системного анализа, теории активных систем, теории информационного управления, согласованного управления в организационных системах, методы и подходы теории искусственного интеллекта.

Исследование показало, что вступление России в Баллонскую конвенцию породило ряд негативных тенденций: снизились эффективность и качество подготовки специалистов, усложнилась возможность интеграции вузов в новую социальноэкономическую систему, произошел отрыв целей подготовки специалистов, а также целей обучения на всех этапах подготовки от целей субъектов экономики. При этом основная ответственность за подготовку специалистов, соответствующих требованиям цифровой экономики, возложена на университеты. Одним из способов преодоления негативных тенденций видится переход вузов на проектно-технологический тип организации своей деятельности. Тогда наиболее перспективной формой управления образовательным проектом становится реализация модели информационного взаимодействия заинтересованных сторон (организаций и университетов) в рамках активных саморазвивающихся сетевых экспертных сред.

В работе представлены структура активной саморазвивающейся сетевой экспертной среды и принципы ее функционирования при формировании стандартов и модели знаний специалиста. Такой подход позволяет рассматривать построение стандартов подготовки и разработку модели знаний специалиста в контексте с корпоративными стратегиями управления интеллектуальным потенциалом. Реализация такого подхода представляет собой многоэтапный процесс сбора, анализа, оценивания и обработки больших массивов информации. Предложена система, обеспечивающая поиск, фильтрацию, обобщение информации, определение ее ценности и перспективности. Утверждается, что способом повышения качества решений по образовательному проекту является синтез технологий сетевой экспертизы и методологии теории активных систем.

В работе показано, что эффективное формирование стандартов подготовки и модели знаний специалистов возможно в рамках самоорганизующихся экспертных сред, которые представляются как активные системы с неоднородными агентами с встречным способом сообщения информации при активном воздействии центра. Эффективная реализация такого подхода предполагает изменение цели системы высшего образования: удовлетворение потребностей в высококвалифицированных специалистах для инновационной экономики. Это позволит обеспечить взаимодействие университетов и организации при управлении их интеллектуальным капиталом в цифровой экономике на новой законодательной базе.

Ключевые слова: цифровая экономика, модель знаний, активная система, система образования, согласованное управление, самоорганизующиеся экспертные среды.

Работа выполнена при финансовой поддержке РФФИ, проект № 170100728.

\section{Литература}

1. Новиков А.М., Новиков Д.А. Образовательный проект (методология образовательной деятельности). М.: Эгвес, 2004.120 с.

2. Виноградов Г.П., Виноградова Н.Г. Самоорганизующиеся сетевые экспертные среды в системах с эндогенным принципом целеуказания // Онтология проектирования. 2016. Т. 6. № 1. С. 36-54. DOI: 10.18287/2223-9537-2016-6-1-39-54.

3. Мамаев В.Я. Модели и алгоритмы для мониторинга и оценки знаний специалистов в компьютерной интеллектуальной обучающей системе // Научное приборостроение. 2001. Т. 11. № 4. С. 84-87.

4. Лобан А.В., Ловцов Д.А. Модель компьютерного обучения с использованием электронного образовательного ресурса нового поколения // Открытое образование. 2017. № 2. C. 47-55. DOI: 10.21686/1818-4243-2017-2-47-55.

5. Найханова Л.В., Дамбаева С.В. Методы и алгоритмы принятия решений в управлении учебным процессом в условиях неопределенности. Улан-Удэ: Изд-во ВСГТУ, 2004. 164 с.

6. Доррер Г.А., Рудакова Г.М., Горбаченко И.М. Вероятностная модель процесса интерактивного обучения // Открытое образование. 2001. № 2 .

7. Леднев В.С. Содержание образования. Сущность, структура, перспективы. М.: Высш. школа, 1991. 224 с.

8. Красильникова В.А. Использование информационных и коммуникационных технологий в образовании. Оренбург: Изд-во ОГУ, 2012.291 с.

9. Информационные и телекоммуникационные технологии в образовании; [под ред. Б. Дендева]. М.: ИИТО ЮНЕСКО, 2013. 320 с.

10. Кузнецов В.Н. Методология согласования в экономических информационных системах: дис. ... д.т.н. М., 1998. 309 с

11. Михалевич В.С., Волкович В.Л. Вычислительные методы в проектировании сложных систем. М.: Наука, 1982. 286 с.

12. Vinogradov G.P. A subjectve rational choice. JPCS, 2017, ser. 803, art. 012176. DOI: 10.1088/1742-6506/803/1/012176

13. Беллман Р., Заде Л. Принятие решений в расплывчатых условиях. В кн.: Вопросы анализа и процедуры принятия решений; [пер. с англ.]. М.: Мир, 1976. С. 172-215.

14. Сетевая экспертиза; [под ред. Д.А. Новикова, А.Н. Райкова]. М.: Эгвес, 2011. 166 с.

15. Виноградов Г.П., Ивашкин Ю.А. Моделирование переговорных процессов в высоко-технологичных производственных системах // Системы управления, связи и безопасности. 2016. № 2. С. 202-248. URL: http://sccs.intelgr.com/archive/2016-02/08-Vinogradov.pdf (дата обращения: 03.10.2018).

16. Бендлер Р. Руководство по изменению личности. М.: Эксмо, 2010. 208 с.

17. Величковский Б.М. Когнитивная наука: Основы психологии познания. В 2 т. М.: Смысл: Академия, 2006. Т. 2. 432 с.

18. Моисеев Н.Н. Математические задачи системного анализа. М.: Наука. Физматлит, 1981. 488 с.

19. Бурков В.Н., Новиков Д.А. Как управлять организациями. М.: Синтег, 2004. 400 с.

20. Калянов Г.Н. Подготовка ИТ-консультантов в разрезе проблематики отечественного консалтинга // Открытое образование. 2017. № 2. C. 40-46. DOI: 10.21686/1818-4243-2017-2-40-46. 